\title{
Efficient plant regeneration and molecular marker-based genetic integrity analysis of Ceropegia lawii Hook: An endemic and endangered herb
}

\author{
Mukta R. Bhamare ${ }^{1}$, Hemantkumar A. Thakur², Jaykumar J. Chavan ${ }^{3 *}$ (D) \\ ${ }^{1}$ Department of Botany, Maratha Vidya Prasarak Samajs, K.T.H.M College, Nashik, India. \\ ${ }^{2}$ Department of Botany, H.P.T. Arts and R.Y.K Science College, Nashik, India. \\ ${ }^{3}$ Department of Botany and Biotechnology, Yashavantrao Chavan Institute of Science (Autonomous), Satara, India.
}

\section{ARTICLE INFO \\ Article history: \\ Received on: July 11, 2021 \\ Accepted on: August 15, 2021 \\ Available online: January 07, 2022}

Key words:

Ceropegia lawii, direct shoot organogenesis, in vitro flowering, ISSR analysis, acclimatization, endangered, endemic, medicinal plant, molecular markers

\begin{abstract}
The present study aimed to optimize the in vitro direct shoot organogenesis system for propagation, in vitro flowering, and genetic fidelity analysis of micropropagated clones of Ceropegia lawii. The efficiency of various plant growth regulator treatments was evaluated during various regeneration stages. Direct shoot organogenesis cultures were established through stem nodal buds on Murashige and Skoog (MS) medium supplemented by 6-benzylaminopurine (BAP, $0.5 \mathrm{mg} / \mathrm{l})$. Maximum frequency of shoot induction and multiplication $(98.5 \%)$ with $14 \pm 0.5$ shoots per explant was attained through the augmentation of BAP $(2.0 \mathrm{mg} / \mathrm{l})$ in the MS medium. In vitro-derived shoots were rooted optimum (89.62\%) with $6.9 \pm 0.1$ numbers of roots while transferring to a half-strength MS medium supplied with indole-3-butyric acid (1.5 mg/l). A maximum number of flowers (5.6 \pm 0.1 ) with $91.33 \%$ induction frequency were reported when microshoots were transferred to the MS medium formulated with BAP $(2.0 \mathrm{mg} / \mathrm{l})$ in combination with sucrose $(175 \mathrm{mM})$. Tissue culture-derived plantlets were adapted best in a mixture of sterile soil, sand, and coco peat $(1: 2: 1)$ with $88 \%$ of survival rate. Inter-simple sequence repeat analysis of regenerated plantlets revealed $99.33 \%$ genetic integrity of in vitro regenerated clones when compared with the donor plant. The findings of the present study reveals that the direct shoot organogenesis approach produces a large number of genetically stable plantlets of $C$. lawii which helps in its conservation and fulfills further industrial necessities.
\end{abstract}

\section{INTRODUCTION}

Ceropegia L. (family Apocynaceae), commonly known as lantern flower, is among the largest genus with over 220 species of starchy tuberous herbs and climbers [1]. These species show a wide range of variations across their habit, habitat, floral arrangement, and ecological point of view [2]. The Indian Biodiversity Catalogue has reported about 57 species, of which 35 are endemic and restricted to narrow pockets in the Western Ghats [3]. Lantern flowers are a very unique group of flowering plants from the variety, scarcity, phytogeography, and reproductive biology point

\footnotetext{
*Corresponding Author

Jaykumar J. Chavan, Department of Botany and Biotechnology,

Yashavantrao Chavan Institute of Science (Autonomous), Satara, India.

E-mail:jaychavansu@gmail.com
}

of view [2]. Numerous lantern flowers have been assessed for their implications as ornamentals, secondary metabolites, and pharmacological usage. Diverse groups of secondary metabolites including tannins, phenolics, alkaloids, flavonoids, ketos, triterpenes, and saponins have been reported from numerous Ceropegia spp. [4,5]. Currently, numerous Ceropegia species are facing hurdles for their survival in nature due manmade activities including overexploitation, habitat destruction, and natural constrains like a lower rate of pollination and non-viability of seeds [5]. These activities continuously lead to a reduced number of natural populations and have enforced this plant group into the International Union for Conservation of Nature categories of flowering plants.

Ceropegia lawii Hook is an erect, perennial herb with starchy tubers naturally grown in the Western Ghats region (Fig. 1A). 
The genus Ceropegia (including C. lawii) has nutritional value due to the presence various sugars, starch, crude fiber, fat, and supplementary important phytochemicals; hence, many species have been routinely practiced as leafy vegetables [5]. Moreover, C. lawii is highly variable in its floral morphology and inflorescence pattern which attracts the attention of botanical enthusiasts, horticulturalists, and gardeners [2]. Currently, this species is facing several constrains such as lack of pollinators, habitat destruction, etc. C. lawii grows on flat mountains where grazing by herbivores is one of the important obstacles for its existence in the wild. Moreover, the collection of leafy vegetables and starchy tubers leads to an indiscriminate collection from the wild. Thorough field investigations have indicated the nonoccurrence of $C$. lawii in its possible zone of existence and now it is considered as endangered taxa [6]. Hence, timely implication of biotechnological tools will support the prevention of the depleting natural population. In vitro regeneration of plantlets by culturing various organs/parts is among the feasible alternative ways for the propagation, protection, and reestablishment of the threatened lantern flowers [5]. Although there is an introductory report on the in vitro regeneration $C$. lawii [7], this study is limited to the development of the protocol for microtuber formation. The assessment of plant tissue culture-derived plantlets for genetic, nutritional, chemical, and other possible implications is very vital. Hence, in the present investigation, the plant regeneration method, viz. shoot multiplication, in vitro flowering, root induction, and acclimatization, has been established for C. lawii. Furthermore, the in vitro-raised clones after their establishment in soil were evaluated for genetic integrity using inter-simple sequence repeat (ISSR) markers.

\section{MATERIALS AND METHODS}

\subsection{Plant Source, Initiation of Cultures, and Controlled Conditions}

Well-grown plants of C. lawii were brought from the Anjaneri hills near Nashik region with prior permission from forest officials. The leaves were removed and the shoot segments were soaked for 10 minutes in $5 \%(\mathrm{v} / \mathrm{v})$ labolene (Qualigens, India). The shoot surface was sterilized in $0.1 \% \mathrm{HgCl}_{2}(\mathrm{w} / \mathrm{v})$ for 4 minutes and were cleaned (thrice) with sterilized distilled water. The single node segments were achieved by cutting the shoot segments and were inoculated in Murashige and Skoog (MS) basal salts [8] lacking phytohormone. The MS salts along with 3\% sucrose, $\mathrm{pH}$ adjusted to 5.8, and gelling agent (Clarigel $0.2 \%$; Himedia, India) were used as the basal medium. After inoculation, the culture vessels were transferred to the incubation room provided with $35 \mu \mathrm{mol}$ $\mathrm{m}^{-2} \mathrm{~s}^{-1}$ light irradiance and $25 \pm 2^{\circ} \mathrm{C}$ temperature.

\subsection{Production of Shoots, Flowers, and Roots under In Vitro Conditions}

The nodal bud explant was used as the source for shoot initiation and proliferation in $C$. lawii. Stem explants having single nodes were transferred to the MS medium augmented with diverse groups of phytohormones either alone, viz. 6-benzylaminopurine (BAP) (0.5-3.0 $\mathrm{mg} / \mathrm{l})$, thidiazuron (TDZ, 0.5-3.0 $\mathrm{mg} / \mathrm{l}$ ), 6-furfurylaminopurine (KN, 0.5-3.0 mg/l), or in mixture with BAP
$(2.0 \mathrm{mg} / \mathrm{l})$ and varied concentrations $(0.5-3.0 \mathrm{mg} / \mathrm{l})$ of kinetin, TDZ, and indole-3-butyric acid (IBA). For the induction of flowers, the apical shoots which were $2-3 \mathrm{~cm}$ in length from tissue culturederived plantlets were inoculated in the MS medium added with diverse mixtures of sucrose $(87-157 \mathrm{mM})$ and BAP $(1.0-4.0 \mathrm{mg} / \mathrm{l})$ as per previously described for other Ceropegia species $[9,10]$. Rooting of well-developed shoots was accomplished on halfstrength MS medium supplemented with diverse concentrations of auxins, viz. IBA $(0.5-2.5 \mathrm{mg} / \mathrm{l})$, indole-3-acetic acid (IAA, $0.5-2.5 \mathrm{mg} / \mathrm{l}$ ), and $\alpha$-naphthaleneacetic acid (NAA, $0.5-2.5 \mathrm{mg} / \mathrm{l}$ ). The vessels were kept in the culture room and provided with 16 hours light and 8 hours dark periods by a white florescence light (Philips, India). Readings for all the experiments were taken after 4 weeks of culture period.

\subsection{Acclimatization and Field Establishment of Micropropagated Plantlets}

Acclimatization of tissue culture-raised clones of $C$. lawii was carried out using a protocol described by Chavan et al. [10]. In vitro-derived, robust, and well-developed plantlets were taken out from culture tubes and the traces of culture medium were removed under running tap water. After Bavistin treatment $(0.3 \% \mathrm{w} / \mathrm{v}$ for 7 minutes), the plantlets were potted in sterilized soil, sand, and coco peat in the proportion of 1:2:1. The plantlets were grown in plastic bag-covered pots, watered with quarter-strength MS basal medium devoid of carbon source, and kept in the laboratory for 4 days. The plastic bags were removed in succession and plantlets were transferred to the greenhouse for ex vitro establishment. Subsequently, the plants were implanted in the soil.

\subsection{ISSR-based evaluation of in vitro-raised clones}

Genomic DNA was extracted from young and healthy leaves of donor and micropropagated plants of C. lawii using the cetyltrimethylammonium bromide method [11]. The final concentration of DNA was made to $20 \mathrm{ng} / 1$ and stored at $-20^{\circ} \mathrm{C}$ for further analysis. ISSR amplification was carried out using the protocol described by Zietkiewicz et al. [12]. Forty-five University of British Columbia (UBC) biotechnology laboratory primers were evaluated based on the good amplification and distinct bands. Polymerase chain reaction (PCR) conditions were maintained as per the method described by Chavan et al. [13]. Experiments were carried out using $40 \mathrm{ng}$ of genomic DNA, $\mathrm{MgCl}_{2}(25 \mathrm{mM})$, and Taq DNA polymerase $(1 \mathrm{U})$. Ten primers were selected on the basis of good amplification with respect to the reproducibility and clear bands. The PCR combination was DNA template, PCR buffer $(10 \times)$, dNTPs $(10 \mathrm{mM})$, Taq DNA polymerase, primer, and $\mathrm{MgCl}_{2}$. Forty amplification cycles were programmed as initial denaturation at $94^{\circ} \mathrm{C}$ for 6 minutes $\left(1\right.$ cycle); denaturation at $94^{\circ} \mathrm{C}$ (for 1 minute); annealing at 48,50 , and $52^{\circ} \mathrm{C}$ ( 1 minute); and extension at $72^{\circ} \mathrm{C}$ for 2 minutes ( 39 cycles); and final extension at $72^{\circ} \mathrm{C}$ for 10 minutes ( 1 cycle).

\subsection{Data Collection and Statistical Examination}

Tissue culture experiments were conducted with a randomized block design with 20 replicates for each treatment and were carried out thrice. The data were evaluated using one-way analysis of 

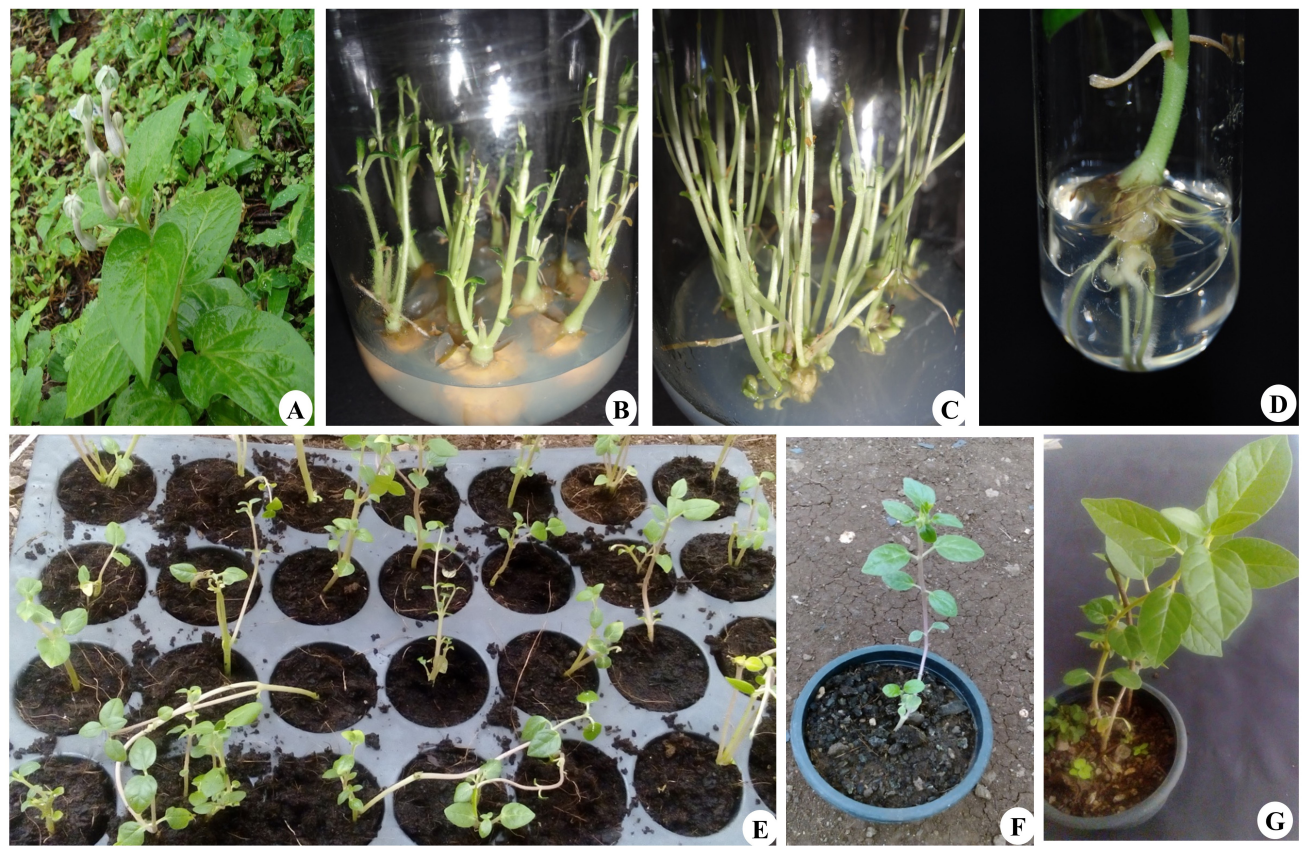

Figure 1: Direct shoot organogenesis and in vitro plant production in C. lawii. (A) Habit; (B and C) Shoot induction and proliferation; (D) In vitro rooting; and (E and G) Hardening and ex vitro establishment of plantlets.

variance and the noteworthy variations among mean values were expressed by Dunnett's multiple comparison test Every band was scored as present (1) and absent (0), and the relationship matrix was attained using NTSYS software.

\section{RESULTS AND DISCUSSION}

\subsection{In Vitro Shoot Production and Rooting of Microshoots}

Culturing of either cell, tissue, or organs of plants is among one of the safest biotechnological routes implicated previously for plant propagation, restoration, and production of industrially important chemical compounds in numerous lantern flower species [5]. In the present investigation, an efficient micropropagation system was developed for large-scale propagation and genetic fidelity assessment of $C$. lawii. The nodal bud explant excised was found suitable for rapid shoot multiplication in C. lawii. The efficiency of the various phytohormones on shoot initiation and subsequent proliferation is presented in Table 1. Individual and combined supplementation of plant growth regulator (PGR) significantly altered the shoot induction and proliferation rate; however, the MS medium lacking PGR did not show any response. Individually, BAP $(2.0 \mathrm{mg} / \mathrm{l})$ was found to be the most efficient for shoot induction $(98.5 \%)$, best number of shoots $(14.5 \pm 0.2)$, and maximum shoot length (10.5 \pm 0.6$)$ (Table 1, Fig. 1B and C). Similarly, improved shoot bud proliferation and production of multiple numbers of shoots in the presence of BAP have been reported previously in other Ceropegia species, including C. attenuata [9], C. bulbosa [14], C. juncea [15], and C. mahabalei [16]. Moreover, the optimum response to direct adventitious shoot bud induction in C. bulbosa from thin cell layer cultures was also observed on the BAP-incorporated MS medium [17]. The rate of shoot production was comparatively lower when MS medium was fortified with individual concentrations of $\mathrm{KN}$ and TDZ when compared to BAP. A maximum of $7.5 \pm 0.2$ and $8.0 \pm 0.1$ shoots were produced when the nodal explant was grown on KN (2.0 mg/l) and TDZ (2.5 mg/l) respectively. However, a mixture of BAP $(2.0 \mathrm{mg} / \mathrm{l})$ with either $\mathrm{KN}(1.5 \mathrm{mg} / \mathrm{l})$ or TDZ $(2.5 \mathrm{mg} / \mathrm{l})$ resulted in the production of $11.0 \pm 0.4$ and $8.8 \pm 0.6$ shoots, respectively. A synergistic effect of two cytokinins was superior for shoot multiplication in Lagenaria siceraria [18] and Chlorophytum borivilianum [19]. The shoot proliferation rate and its number was increased when the shoots were transferred for sequential subcultures on fresh media of known compositions.

Successful attainment of the in vitro plant regeneration approach confides on root induction and growth of regenerated shoots under controlled conditions [20]. Well-developed in vitro roots empower the plantlets to establish in the soil and promote self-perpetuation under ex vitro conditions. Microshoots of $C$. lawii were rooted when transferred to half-strength MS medium added with varied different concentrations $(0.5-2.5 \mathrm{mg} / \mathrm{l})$ of auxins (IAA, NAA, and IBA). The response of auxins during in vitro root production in $C$. lawii is presented in Table 2. Among the auxins tested, IBA proved to be superior when compared to IAA and NAA. Moreover, the roots produced in the IBA-supplemented medium were thicker, having an added advantage during the acclimatization process. A similar observation was made previously in Ceropegia noorjahaniae [21]. The highest root induction frequency $(89.62 \%)$ and optimal root number $(6.9 \pm 0.1)$ were attained using IBA at $1.5 \mathrm{mg} / 1$ (Table 2, Fig. 1D). The practicality of IBA during in vitro root induction has been noted previously for Ceropegia panchganiensis [10] and Mentha arvensis [22]. In vitro grown plantlets with three to four pairs of healthy leaves and well-grown roots were transferred to plastic pots having a sterilized planting substrate (soil, sand, and coco peat in the 1:2:1 ratio). A similar 
Table 1: Effect of different plant growth regulators on axillary bud breaking from nodal explant of Ceropegia lawii.

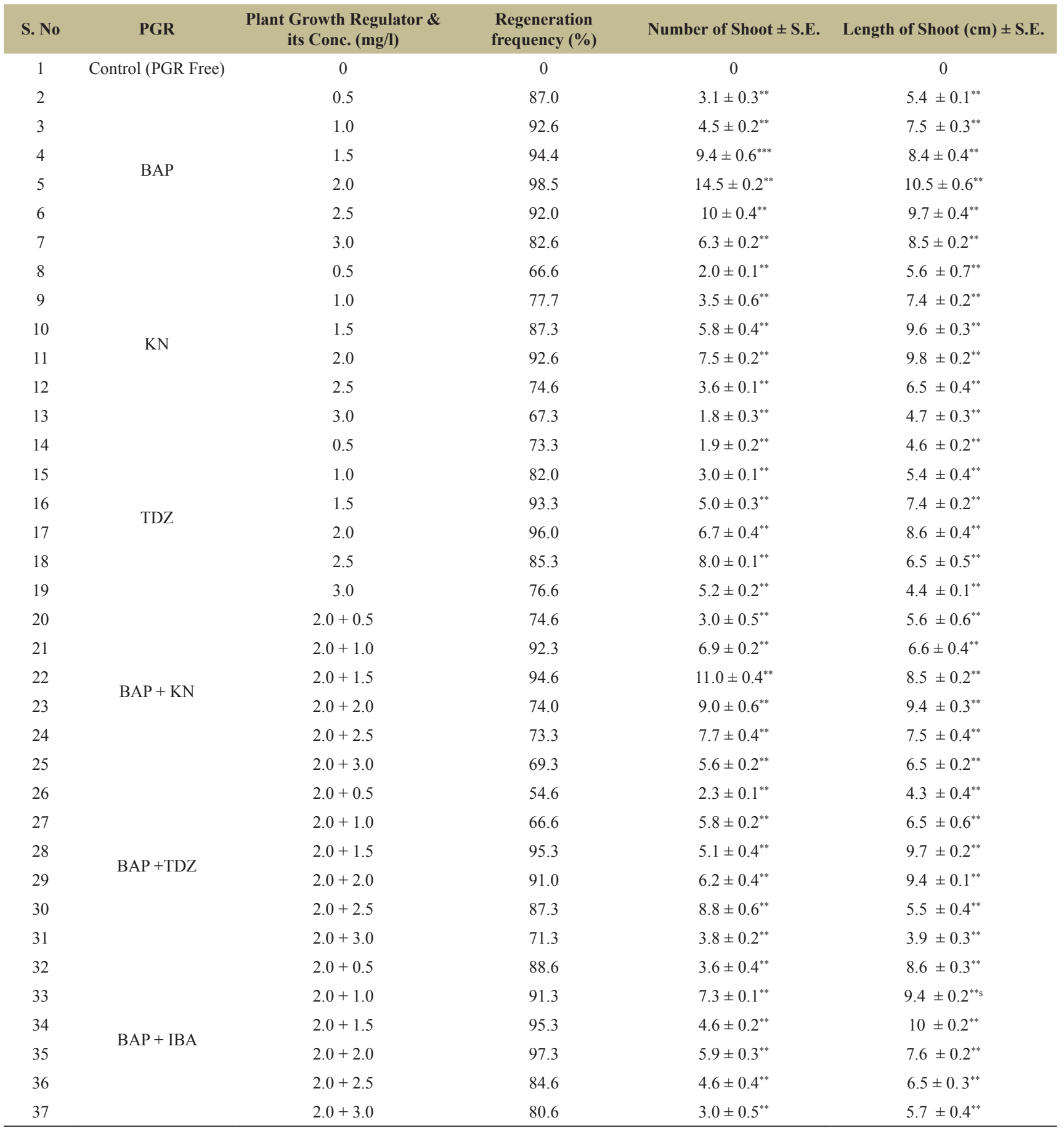

All values represent mean \pm S.E. of 20 replicates/treatment and the experiments were repeated thrice. The values are significantly different at ns-non significant, $* p<0.05$ and $* * p<0.01$ level when compared by Dunnett multiple comparisons test using one-way ANOVA.

composition was found to be most suitable for hardening of micropropagated plantlets of C. panchganiensis [10], Ceropegia evansii [13], and Ceropegia santapaui [23]. In this study, the plantlets were transferred to a greenhouse for further hardening and acclimatization to field conditions after 1 week's exposure to controlled laboratory conditions. Subsequently, the plantlets were moved to soil where $88 \%$ survival rate was recorded. Regenerants showed homogeneity lacking any morphological differences (Fig. $1 \mathrm{E}-\mathrm{G})$.

\subsection{In Vitro Flowering}

Due to the fluctuations in environmental factors during ex vitro growth, the flower induction process in most of the flowering 
Table 2: Effect of auxins on in vitro rooting of regenerated shoots of $C$. lawii on half strength MS medium.

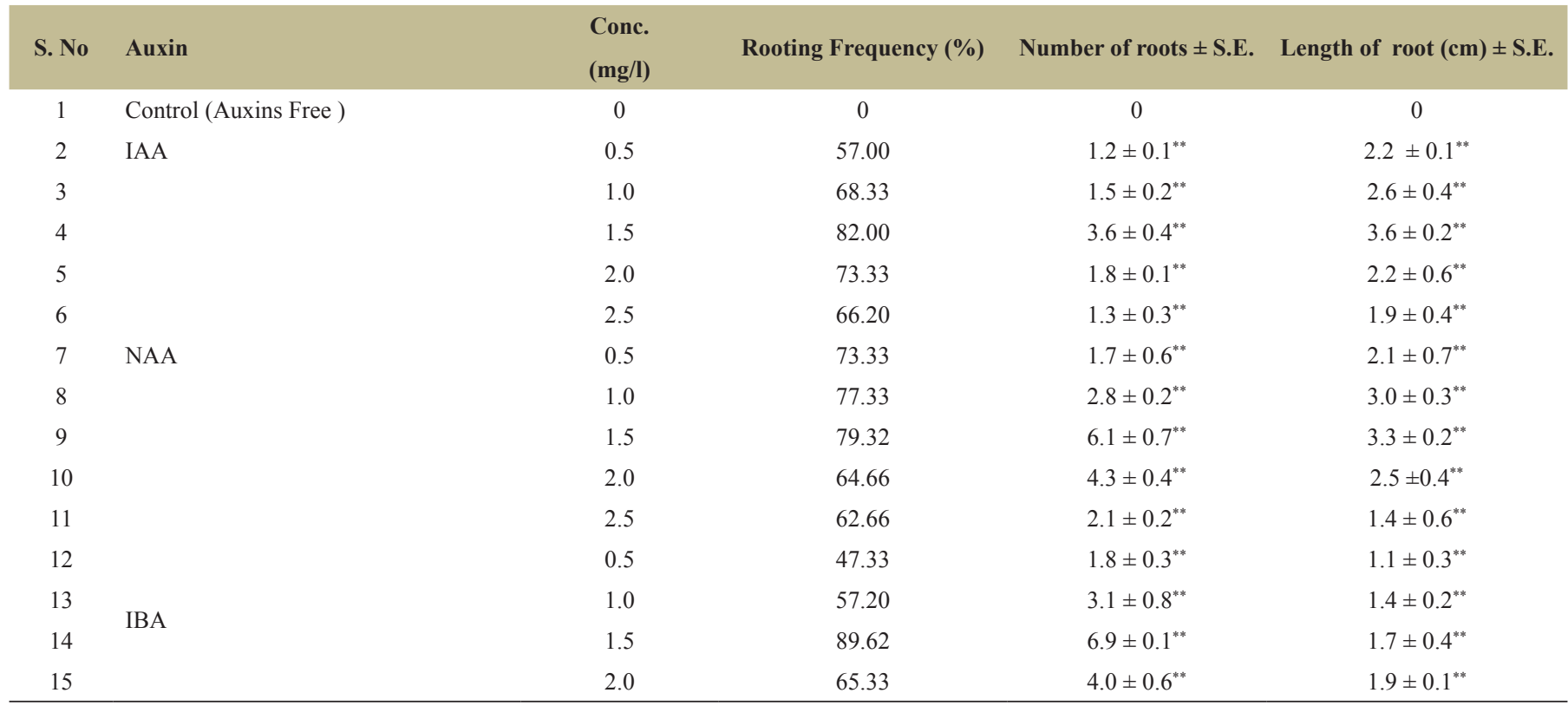

All values represent mean \pm S.E. of 20 replicates/treatment and the experiments were repeated thrice. The values are significantly different at ns-non significant, $* p<0.05$ and $* * p<0.01$ level when compared by Dunnett multiple comparisons test using one-way ANOVA.

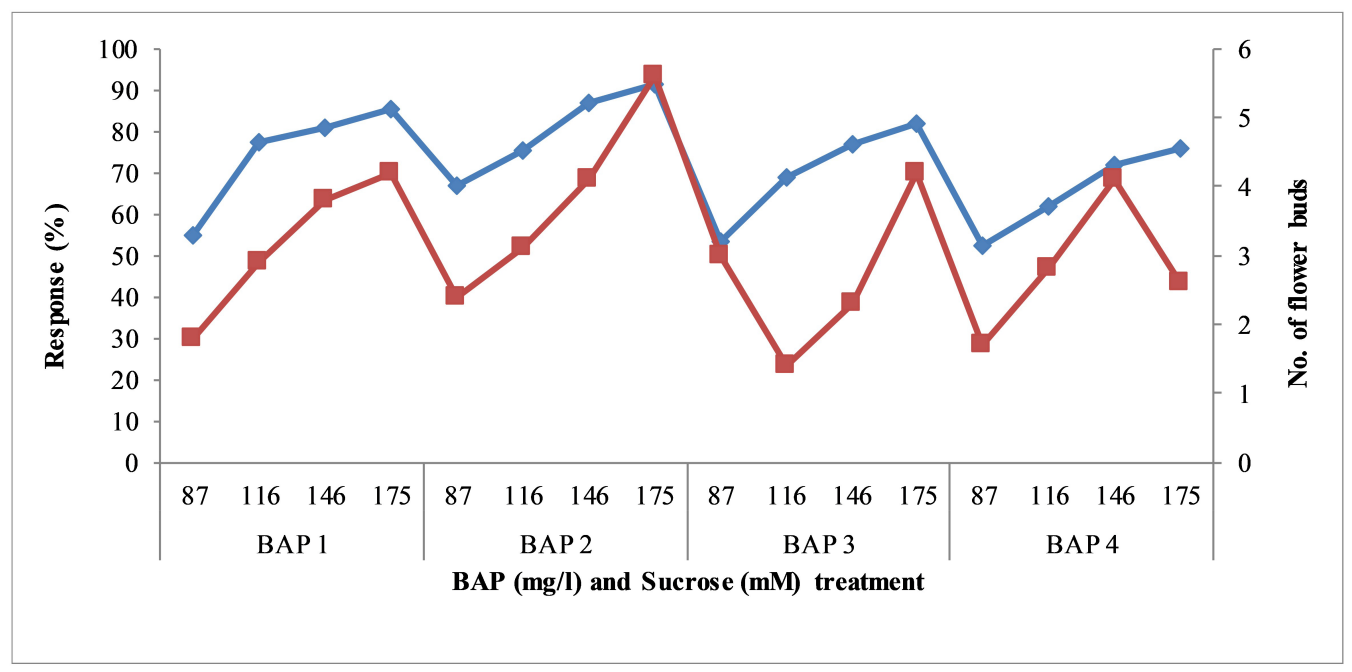

Figure 2: Efficiency of BAP and sucrose on flower induction in C. lawii.

plants has been hampered, which has led to the depletion of the natural population. In vitro flower induction under controlled laboratory conditions is among the potential alternatives to study the flower induction mechanism $[9,10]$. In this study, diverse BAP concentrations and sucrose significantly altered the frequency of in vitro induction flower buds in C. lawii (Fig. 2). Apical shoots (with three to four pairs of leaves) were inoculated in the MS medium fortified with $2.0 \mathrm{mg} / \mathrm{l}$ of BAP and $175 \mathrm{mM}$ of sucrose, resulting in the induction of $5.6 \pm 0.1$ flower buds in $91.33 \%$ cultures (Fig. $3 \mathrm{~A}$ $\&$ B). The results of present investigation were found be superior over previously published reports on C. lawii [24].

\subsection{Genetic Fidelity}

The production of true-to-type plants is the ultimate aim of most of in vitro plant regeneration systems, hence the assessment of clonal fidelity among mother plants and regenerants using molecular markers among major prerequisites in any in vitro plant regeneration process. Initially, 45 ISSR primers were screened; among them the 10 most-suited primers were identified on the basis of notable and reproducible bands in $C$. lawii. It resulted in the production of 41 distinct visible bands in the size of $250 \mathrm{bp}$ (UBC-812) to 8,000 bp (UBC-815) among the 10 ISSR primers. The number of scorable bands ranged from 2 (UBC-807 and 
Table 3: Details of ISSR primers and amplified fragments generated in C. lawii.

\begin{tabular}{|c|c|c|c|c|c|c|c|}
\hline \multirow{2}{*}{ S. No. } & \multirow{2}{*}{ Primer Code } & \multirow{2}{*}{ Primer sequence ( $\left.5^{\prime}-3^{\prime}\right)$} & \multirow{2}{*}{$\begin{array}{c}\text { Annealing temp. } \\
\text { (0C) }\end{array}$} & \multirow{2}{*}{$\begin{array}{c}\text { Number of bands/ } \\
\text { primer }\end{array}$} & \multicolumn{2}{|c|}{ Total number of bands amplified } & \multirow{2}{*}{ Size range (bp) } \\
\hline & & & & & Monomorphic & Polymorphic & \\
\hline 1 & UBC - 801 & $(\mathrm{AT}) 8 \mathrm{~T}$ & 48 & 4 & 44 & - & $350-1500$ \\
\hline 2 & UBC - 807 & $(\mathrm{AG}) 8 \mathrm{~T}$ & 49 & 2 & 18 & 1 & $500-1500$ \\
\hline 3 & UBC - 809 & $(\mathrm{AG}) 8 \mathrm{G}$ & 52 & 5 & 55 & - & $500-2000$ \\
\hline 4 & UBC - 811 & $(\mathrm{GA}) 8 \mathrm{C}$ & 54 & 5 & 55 & - & $400-1250$ \\
\hline 5 & $\mathrm{UBC}-812$ & (GA)8A & 50 & 7 & 77 & - & $300-1500$ \\
\hline 6 & UBC - 813 & (CT) $8 \mathrm{~T}$ & 48 & 4 & 43 & 1 & $300-1100$ \\
\hline 7 & UBC - 814 & (CT)8A & 49 & 2 & 22 & - & $750-1500$ \\
\hline 8 & UBC - 815 & (CA)8G & 55 & 5 & 55 & - & $300-3000$ \\
\hline 9 & UBC - 822 & (C) $8 \mathrm{~A}$ & 48 & 3 & 33 & - & $250-750$ \\
\hline 10 & UBC - 823 & (TC) $8 \mathrm{C}$ & 55 & 4 & 43 & 1 & $300-1250$ \\
\hline \multicolumn{4}{|c|}{ Total } & 41 & $445(99.33 \%)$ & \multicolumn{2}{|c|}{$3(0.67 \%)$} \\
\hline
\end{tabular}

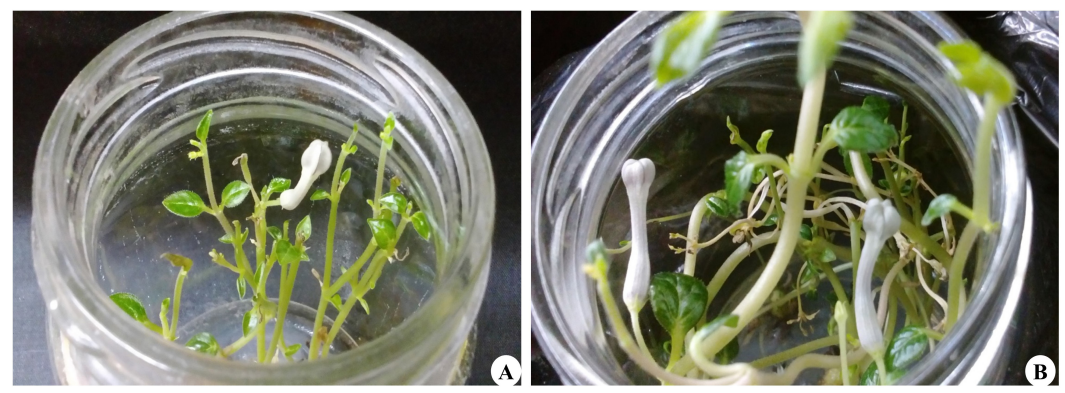

Figure 3: (A and B) In vitro flowering in C. lawi $i$.

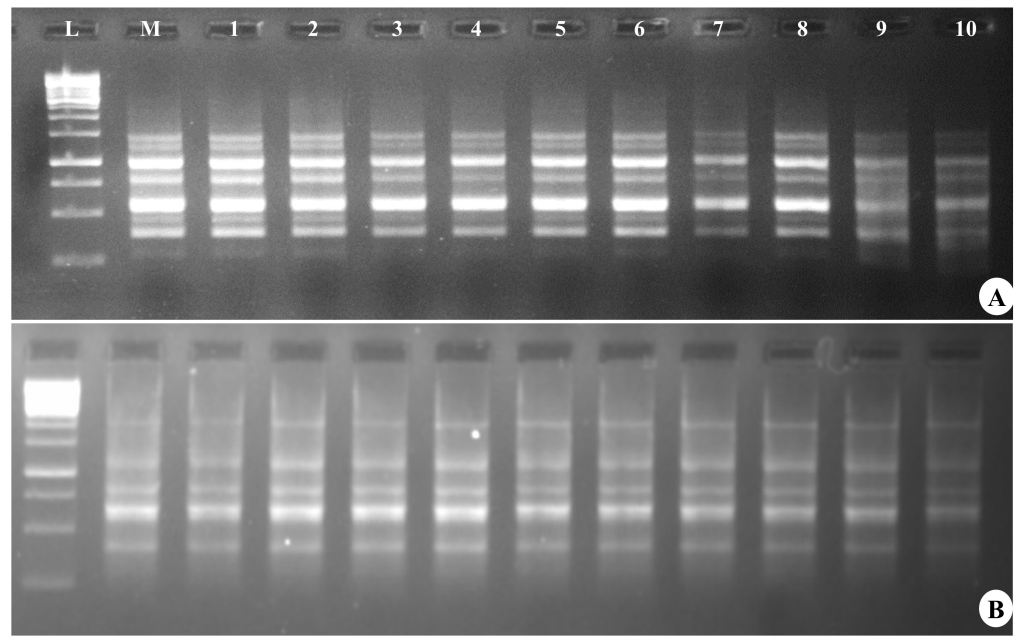

Figure 4: ISSR fingerprints of mother and micropropagated plants of C. lawii. (A) UBC-12 and (B) UBC-815.

UBC-814) to 7 bands per primer (UBC-812). A total of 448 bands were produced by 10 ISSR primers in a donor and 10 randomly selected micropropagated clones of $C$. lawii (Table 3). The results of ISSR fingerprints revealed $99.33 \%$ genetic similarity among mother and micropropagated plants (Table 3, Fig. 4A and B). These findings are in agreement with published reports where ISSR proved genetic reliability in micropropagated plantlets of Ceropegia species [10,13,23]. 


\section{CONCLUSION}

In conclusion, high throughput direct shoot organogenesis approach has been developed from nodal bud explants of $C$. lawii-a category and concentration of phytohormones significantly affected during different in vitro regeneration steps. The high degree of similarity in ISSR fingerprint meant a high degree of resemblance to their donor plant. Therefore, the high percentage of regeneration and admired genetic stability are reliable causes advising that the method can be used for large-scale propagation, conservation, and benefit in breeding programs.

\section{AUTHORS' CONTRIBUTIONS}

All authors made substantial contributions to the conception and design, acquisition of data, or analysis and interpretation of data; they took part in drafting the article or revising it critically for important intellectual content; agreed to submit to the current journal; gave final approval for the version to be published; and agreed to be accountable for all aspects of the work. All the authors are eligible to be an author as per the International Committee of Medical Journal Editors requirements/guidelines.

\section{FUNDING}

There is no funding to report.

\section{CONFLICTS OF INTEREST}

The authors report no financial or any other conflicts of interest in this work.

\section{ETHICAL APPROVALS}

This study did not involve experiments on animals or human subjects.

\section{PUBLISHER'S NOTE}

This journal remains neutral with regard to jurisdictional claims in published institutional affiliation.

\section{REFERENCES}

1. APG III. An update of the angiosperm phylogeny group classification for the orders and families of flowering plants. Bot J Linn Soc 2009;161:105-21.

2. Kambale S, Yadav S. Taxonomic revision of Ceropegia (Apocynaceae: Ceropegieae) in India. Rheedea 2019;29(1):1-115.

3. Karthikeyan S, Sanjappa M, Moorthy S. Flowering plants of Indiadicotyledons, vol. 1 (Acanthaceae-Avicenniaceae). Botanical Survey of India, Kolkata, India, pp 184-299, 2009.

4. Chavan JJ, Gaikwad NB, Kshirsagar PR, Dixit GB. Total phenolics, flavonoids and antioxidant properties of three Ceropegia species from Western Ghats of India. South Afr J Bot 2013;88: 273-7.

5. Chavan JJ, Gaikwad NB, Dixit GB, Yadav SR, Bapat VA. Biotechnological interventions for propagation, conservation and improvement of 'lantern flowers' (Ceropegia spp.). South Afr J Bot 2018;114:192-216.

6. Gaikwad S, Gore R, Garad K, Gaikwad S. Endemic flowering plants of Northern Western Ghats (Sahyadri Ranges) of India: a checklist. Check List 2014;10(3):461-72.
7. Pandit SS, Nair AK, Naik DD. Towards conservation of threatened Ceropegia species endemic to a biodiversity hotspot: in vitro microtuber production and proliferation, a novel strategy. J For Sci 2008;24(2):79-88.

8. Murashige T, Skoog F. A revised medium for rapid growth and bioassays with tobacco tissue culture. Physiol Plantarum 1962;15:47397.

9. Chavan JJ, Nimbalkar MS, Adsul AA, Kamble SS, Gaikwad NB, Dixit GB, Gurav RV, Bapat VA, Yadav SR. Micropropagation and in vitro flowering of endemic and endangered plant Ceropegia attenuata Hook. J Plant Biochem Biotechnol 2011;20(2):276-82.

10. Chavan JJ, Gaikwad NB, Yadav SR. High multiplication frequency and genetic stability analysis of Ceropegia panchganiensis, a threatened ornamental plant of Western Ghats: conservation implications. Sci Hortic 2013;161:134-42.

11. Saghai-Maroof MA, Soliman KM, Jorgesen RA, Allard RW Ribosomal DNA spacer length polymorphisms in barley Mendelian inheritance, chromosomal location and population dynamics. Proc Natl Acad Sci USA 1984;81:8014-8018.

12. Zietkiewicz E, Rafalski A, Labuda D. Genome fingerprinting by simple sequence repeat (SSR) - anchored polymerase chain reaction amplification. Genomics 1994;20:176-83.

13. Chavan JJ, Gaikwad NB, Kshirsagar PR, Umdale SD, Bhat KV, Dixit GB, Yadav SR. Highly efficient in vitro proliferation and genetic stability analysis of micropropagated Ceropegia evansii by RAPD and ISSR markers: a critically endangered plant of Western Ghats. Plant Biosyst 2015;149:442-50.

14. Dhir R, Shekhawat GS. Production, storability and morphogenic response of alginate encapsulated axillary meristems and genetic fidelity evaluation of in vitro regenerated Ceropegia bulbosa: a pharmaceutically important threatened plant species. Ind Crops Prod 2013;47:139-44.

15. Balakrishnan S, Ponnusamy S, Rajendran V, Vellaichamy T. In vitro multiple shoot induction of selected Ceropegia species - medicinally important plants. Int J Conserv Sci 2015;6(2):253-60.

16. Upadhye AS, Waghamode PB, Dhavare PM, Gaikwad NS. Standardization and re-introduction of critically endangered Ceropegia mahabalei Hemadri and Ansari by in vitro propagation. Ann Plant Sci 2015;4(2):987-93.

17. Dhir R, Shekhawat GS. In vitro propagation using transverse thin cell layer culture and homogeneity assessment in Ceropegia bulbosa Roxb. J Plant Growth Regul 2014;33:820-30.

18. Saha S, More H, Hattori K. Synergistic effect of kinetin and benzyl adenine plays a vital role in high frequency regeneration from cotyledon explants of bottle gourd (Lagenaria siceraria) in relation to ethelene production. Breed Sci 2017;57:197-202.

19. Ashraf MF, Aziz MA, Kemat N, Ismail I. Effect of cytokinin types, concentrations and their interactions on in vitro shoot regeneration of Chlorophytum borivilianum Sant. \& Fernandez. Electron J Biotechnol 2014;17(6):275-9.

20. Dewir YH, Murthy HN, Ammar MH, Alghamdi SS, Al-Suhaibani NA, Alsadon AA, Paek KY. In vitro rooting of leguminous plants: difficulties, alternatives, and strategies for improvement. Hortic Environ Biotechnol 2016;57(4):311-22.

21. Chavan JJ, Nalawade AS, Gaikwad NB, Gurav RV, Dixit GB, Yadav SR. An efficient in vitro regeneration of Ceropegia noorjahaniae: an endemic and critically endangered medicinal herb of the Western Ghats. Physiol Mol Biol Plants 2014;20(3):405-10.

22. Faisal M, Alatar AA, Hegazya AK, Alharbi SA, El-Sheikha M, Okla MK. Thidiazuron induced in vitro multiplication of Mentha arvensis and evaluation of genetic stability by flow cytometry and molecular markers. Ind Crops Prod 2014;62:100-6.

23. Chavan JJ, Gaikwad NB, Umdale SD, Kshirsagar PR, Bhat KV, Yadav SR. Efficiency of direct and indirect shoot organogenesis, molecular profiling, secondary metabolite production and antioxidant activity 
of micropropagated Ceropegia santapaui. Plant Growth Regul 2014;72:1-15.

24. Nair AK, Naik DD, Pandit SS. High frequency in vitro flowering in six species of Ceropegia. J Plant Biol 2007;50:374-7.
How to cite this article:

Bhamare MR, Thakur HA, Chavan JJ. Efficient plant regeneration and molecular marker-based genetic integrity analysis of Ceropegia lawii Hook: An endemic and endangered herb. J Appl Biol Biotech 2022;10(01):95-102. 